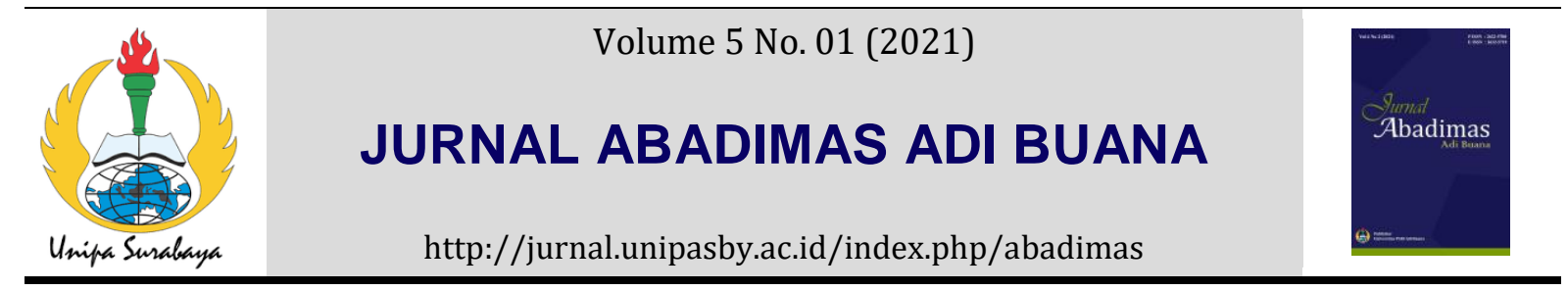

\title{
WASTAFEL PORTABEL SISTEM INJAK SEBAGAI PIRANTI PENDUKUNG PROTOKOL KESEHATAN DI MASA ADAPTASI BARU
}

\author{
Wahyu Dwi Mulyono ${ }^{1 *}$, Gde Agus Yudha Prawira Adistana ${ }^{2}$ Heri Suryaman $^{3}$ \\ ${ }^{1}$ Program Studi S1 Pendidikan Teknik Bangunan, Fakultas Teknik, Universitas Negeri Surabaya \\ *Email: wahyumulyono@unesa.ac.id
}

\begin{abstract}
Informasi Artikel Abstrak
Kata kunci :

Wastafel Portabel,

Sistem Injak, Adaptasi

Baru

Diterima: 08-03-2021

Disetujui: 22-04-2021

Dipubikasikan: 14-07-

2021

Penyebaran pandemi COVID-19 dapat diminimalisir dengan melakukan upaya non medis seperti social distancing dan Gerakan Masyakat Sehat (GERMAS). Salah satu hal sederhana yang dapat dilakukan adalah dengan membersihkan area tangan (telapak tangan). Permasalahan yang terjadi di lapangan adalah terbatasnya tempat cuci tangan yang mudah dijangkau. Oleh karena itu, tujuan pengabdian ini adalah untuk mengadakan dan mendistribusikan wastafel portabel dengan sistem injak ke Sekolah Menengah Kejuruan (SMK). Pelaksanaan pengabdian kepada masyarakat diharapkan mampu mendorong masyarakat agar lebih rajin untuk membersihkan area tangan sehingga resiko terjangkit COVID-19 dapat dikurangi. Pengabdian ini dilaksanakan di SMK Negeri 2, 3, 5, dan 7 Surabaya. Pelaksanaan PKM dimulai dari survey dan koordinasi dengan mitra, kemudian pembuatan wastafel dan pendistribusian wastafel ke SMK. Hasil kegiatan berupa pengadaan 8 buah wastafel di SMK yang ditempatkan di depan ruang kelas, dan bengkel kerja yang sebelumnya belum ada wastafel sistem injak, sekarang sudah ada. Respon mitra terhadap pengadaan wastafel ini sangat baik dan sangat bermanfaat bagi sekolah.
\end{abstract}

\section{Keywords :}

Portable Sink, Stepping

System, New Adapt

\section{Abstract}

The spread of the COVID-19 pandemic can be minimized by carrying out non-medical efforts such as social distancing and the Healthy Community Movement (GERMAS). One of the simple things that can be done is to clean the hand area (palms). The problem that occurs in the field is the limited number of places to wash hands that are easily accessible. Therefore, the purpose of this service is to organize and distribute portable sinks with a trampling system to Vocational High Schools (SMK). The implementation of community service is expected to be able to encourage people to be more diligent in cleaning the hand area so that the risk of contracting COVID-19 can be reduced. This service was carried out at SMK Negeri 2, 3, 5, and 7 Surabaya. The implementation of PKM starts from surveying and coordination with partners, then making sinks and distributing the sinks to SMK. The results of the activity are the provision of 8 sinks at the SMK which is placed in front of the classrooms, and a workshop that previously did not have a sink in the trampling system, it already exists. The response of partners to the provision of this sink is very good and very useful for schools. 


\section{PENDAHULUAN}

Berbagai upaya dilakukan di seluruh dunia untuk mengembangkan vaksin dan terapi COVID-19 dan mengakhiri pandemi yang mengancam untuk menginfeksi sebagian besar populasi planet ini dan membunuh jutaan orang. Secara garis besar, upaya tersebut dibedakan menjadi dua, yakni upaya medis dan non medis. Salah satu upaya non medis yang digalakkan oleh pemerintah adalah dengan Gerakan Masyarakat Sehat (GERMAS). Pola hidup sehat diyakini dapat menurunkan resiko terinfeksi COVID-19.

Salah satu upaya yang dapat dilakukan untuk mewujudkan pola hidup sehat adalah dengan rutin mencuci tangan. Terdapat dua metode dalam membersihkan tangan yaitu mencuci tangan dengan sabun dan dengan hand sanitizer. Menurut (Nakoe et al., 2020) mencuci tangan dengan sabun lebih efektif dari pada hand sanitizer. Studi yang dilakukan oleh (Pogrebna \& Kharlamov, 2020) menunjukkan bahwa negara-negara di mana orang tidak memiliki kebiasaan mencuci tangan secara otomatis cenderung memiliki paparan COVID-19 yang jauh lebih tinggi.

Belum menyeluruhnya vaksinasi mewajibkan umat manusia untuk menemukan cara mengurangi potensi risiko infeksi. Sering mencuci tangan dengan sabun selama setidaknya 20 detik secara luas disarankan sebagai tindakan pencegahan terhadap COVID-19. (Manikandan, 2020) menyatakan bahwa untuk mengatasi ancaman global COVID-19 ini, kombinasi tindakan pencegahan seperti menjaga jarak jarak, mencuci tangan, dan memakai masker adalah utama yang dapat mengurangi penularan COVID-19 di masyarakat.

Menurut (Peraturan Menteri Kesehatan Republik Indonesia No. 3 Tahun 2014 Tentang Sanitasi Total Berbasis Masyarakat, 2014) mencuci tangan yang benar adalah salah satu unsur dari tiga pilar pembangunan Indonesia bidang kesehatan yakni berpola hidup sehat. Adapun pilar yang lain adalah pengkondisian lingkungan sehat serta penyediaan layanan kesehatan yang representatif dan terjangkau semua kalangan.

.Mencuci tangan dengan sabun menurut WHO adalah cara yang tepat sesuai kesehatan (World Health Organization, 2020). Selanjutnya menurut (Ambarwati, E. R., \& Prihastuti, 2019) karena sabun dapat membunuh kuman atau virus yang menempel di tangan, maka usaha yang paling sederhana untuk menegakkan pilar hidup sehat adalah dengan gemar cuci tangan. Usaha mencucitangan yang oleh masyarakat dianggap sepele ini ternyata dapat ber kontribusi penting pada upaya pencegehan COVID-19 (Ibrahim, I., Kamaluddin, K., Mintasrihardi, M., Junaidi, A. M., \& Abd Gani, 2020).

Tangan adalah bagian tubuh kita yang paling banyak tercemar kotoran dan bibit penyakit. Ketika memegang sesuatu, dan berjabat tangan, tentu ada bibit penyakit yang melekat pada kulit tangan kita. Telur cacing, virus, kuman dan parasit yang mencemari tangan, akan menpel pada orang lain yang 
kita ajak berjabat tangan atau bahkan saat kita makan dengan tangan yang tidak bersih, kotoran tertelan dan sudah barang tentu akan menggangu pencernaan (Ambarwati, E. R., \& Prihastuti, 2019).

Selain bertransmisi melalui tangan, kotoran, penyakit serta virus pada umumnya juga dapat melekat pada barang-barang lain seperti gagang pintu, uang, alatalat makan, juga permainan. Ketika alat-alat tadi dipegang dan kemudian tangan tidak dibersihakn maka akan sangat mungkin kita dapat tertular penyakit termasuk virus. (Kushartanti, 2012) menyatakan bahwa mencuci tangan dengan benar dan sesuai kesehatan amatlah penting agar jenis virus dan penyakit tidak masuk ke dalam tubuh manusia.

Kondisi di lapangan seringkali membuat beberapa orang kesulitan untuk mencuci tangannya. Pemerintah Kota Surabaya dan beberapa instansi telah menyediakan beberapa bak cuci tangan portable namun mengingat luasnya kota Surabaya, upaya ini dirasa masih belum optimal.

Seiring dengan dicetuskannya masa adaptasi baru, cuci tangan menjadi sebuah kebiasaan yang mandatori. Tentunya hal ini hanya bisa terwujud apabila didukung oleh sarana yang memadai yakni bak cuci tangan yang mudah untuk diisi ulang, mudah digunakan, meminimalisir kontak, dan dapat dipindah-pindah. Bak cuci tangan juga efektif untuk mencuci muka, karena selain dengan mencuci tangan juga harus rutin mencuci muka untuk membersihkan area wajah dapat mencegah infeksi virus (Przekwas \& Chen, 2020).

Sekolah Menengah Kejuruan (SMK) mendapat pengaruh yang sangat besar dari Pandemi COVID-19. SMK mempunyai proporsi praktik lebih besar dari pada teori. Praktik tidak bisa digantikan dengan online, sehingga tetap dilakukan di sekolah dengan melaksanakan protokol kesehatan yang ketat, serta dengan metode bergantian atau shift. Terdapat empat SMK Negeri di Surabaya yang menjadi sasaran PKM ini yaitu SMK Negeri 2 Surabaya, SMK Negeri 3 Surabaya, SMK Negeri 5 Surabaya, dan SMK Negeri 7 Surabaya yang masuk dalam SMK Teknologi dan Industri yang berdasarkan Menteri Pendidikan dan Kebudayaan Republik Indonesia bahwa pada tahun 2021 sudah diperbolehkan sekolah tatap muka dengan syarat kesiapan semua pihak baik sekolah maupun siswa nya dan atas izin dari wali siswa.

Tujuan dari kegiatan PKM ini adalah untuk mengadakan dan mendistribusikan wastafel atau bak cuci tangan portabel dengan sistem injak ke Sekolah Menengah Kejuruan (SMK) yang mudah untuk diisi ulang, mudah digunakan, meminimalisir kontak, dan dapat dipindah-pindah.

\section{METODE}

Sebagai upaya mengisi gap antara kebutuhan dan permintaan tempat cuci tangan yang praktis namun efektif, Solusi yang ditawarkan adalah dengan mengadakan dan mendistribusikan wastafel portabel dengan sistem injak ke Sekolah Menengah Kejuruan (SMK) yang mudah digunakan, dapat meminimalisir kontak, dan mudah dipindahkan. 
Lokasi pelaksanaan PKM ini adalah di empat SMK yaitu:

1. SMK Negeri 2 Surabaya dengan alamat di Jl. Tentara Genie Pelajar No.26 Surabaya

2. SMK Negeri 3 Surabaya dengan alamat di Jl. Jend. A.Yani No.319, Gayungan, Surabaya.

3. SMK Negeri 5 Surabaya dengan alamat di Jl. Prof. Dr. Mustopo No, 167 - 169 Surabaya

4. SMK Negeri 7 Surabaya dengan alamat Jl. Pawiyatan No. 2 Bubutan Surabaya

Tahap pelaksanaan PKM ini adalah sebagai berikut:

1. Tahap Persiapan, sebagai langkah awal, akan dilakukan koordinasi yaitu dengan Tim PKM dan koordinasi dengan pihak SMK Negeri 2, 3, 5, dan 7 Surabaya. Koordinasi dengan Tim PKM untuk mendapatkan masukan, saran, dan solusi untuk teknik pelaskanaan PKM.

2. Tahap pembuatan dan perakitan, selanjutnya tim akan menentukan model produk yang harus diproduksi beserta teknik penyaluran yang paling efektif sesuai dengan protokol kesehatan. Tim membuat desain wastafel portabel yang sesuai untuk sekolah dan efektif. Desain yang telah dibuat kemudian dijadikan dasar untuk membuat wastafel, mulai dari perakitan sampai selesai.

3. Tahap distribusi dan evaluasi, wastafel yang telah siap kemudian didistribusikan ke sekolahsekolah yaitu di SMK Negeri 2, 3, 5, dan 7 Surabaya. Proses evaluasi kegiatan dilakukan dengan menampung aspirasi dan menganalisis hambatan yang dialami di lapangan serta memberikan masukan agar kegiatan seperti ini lebih berhasil di masa mendatang.

\section{HASIL DAN PEMBAHASAN}

Kegiatan PKM ini dibagi menjadi tiga tahapan yaitu koordinasi dan survey, pembuatan wastafel, dan distribusi wastafel ke SMK. Uraian dari tahapan-tahapan kegiatan PKM ini akan dijelaskan sebagai berikut.

\section{Koordinasi dan Survey}

Tahap pertama yaitu melakukan survey dan koordinasi ke sekolah-sekolah tempat dilaksakannya PKM. Tahap ini didapatkan persetujuan PKM oleh pihak SMK Negeri 2 Surabaya, SMK Negeri 3 Surabaya, SMK Negeri 5 Surabaya dan SMK Negeri 7 Surabaya. Hasil survey telah didapatkan target jumlah wastafel yang akan didistribusikan ke setiap sekolah yaitu dua wastafel portabel sistem injak, sehingga total terdapat delapan wastafel yang akan didistribusikan ke sekolah. Dokumentasi koordinasi dengan pihak sekolah dapat dilihat pada Gambar 1 dan Gambar 2. 


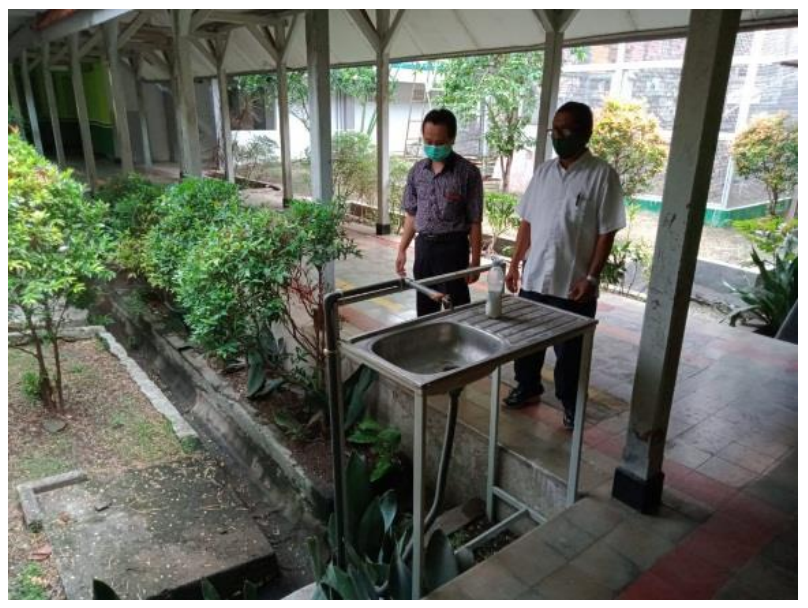

Gambar 1. Koordinasi dan Survey di SMK Negeri 2 Surabaya

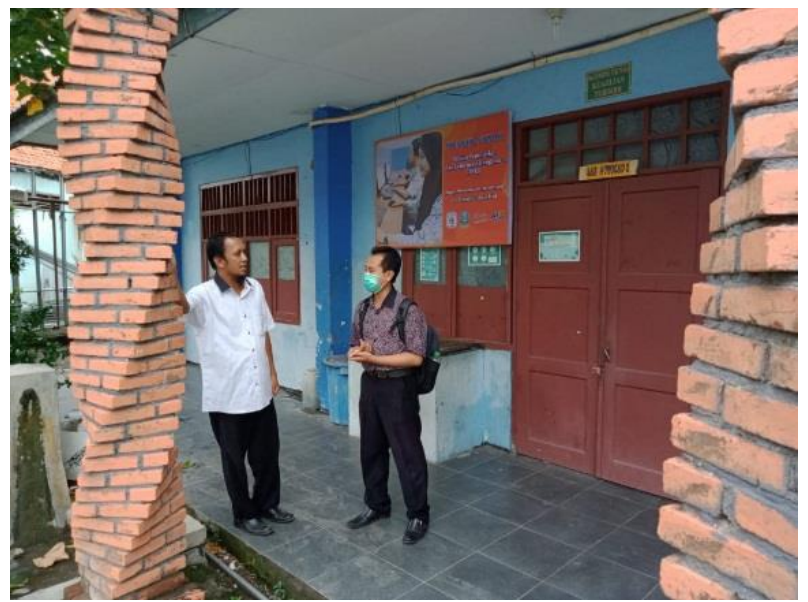

Gambar 2. Koordinasi dan Survey di SMK Negeri 7 Surabaya

\section{Pembuatan Wastafel}

Tahap kedua adalah melakukan pembuatan wastafel. Tahap ini dimulai dari pembuatan desain, pembelian alat dan bahan yang dibutuhkan, pelaksanaan pekerjaan, dan finishing pekerjaan. Wastafel yang akan dibuat didesain dengan model portabel dan sistem injak. Portabel berarti tidak membutuhkan instalasi khusus, dan dapat ditempatkan dimanapun walau tidak ada saluran air untuk pembuangan air bekas cuci tangan karena sudah terdapat tandon tempat air kotor. Sistem injak yaitu untuk melakukan cuci tangan dengan mengeluarkan sabun serta air tidak menggunakan tangan, tetapi dengan pedal yang diinjak dengan kaki. Desain wastafel dapat dilihat pada Gambar 3. 


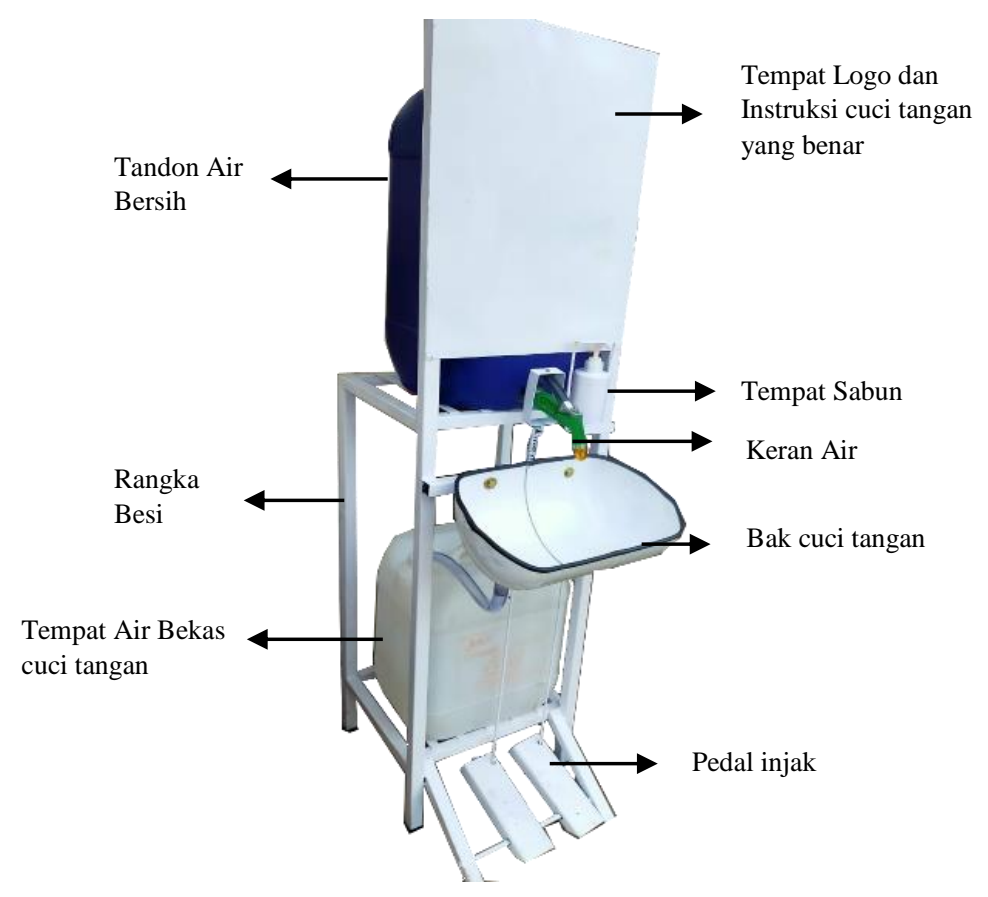

Gambar 3. Desain Wastafel Portabel dengan Sisitem Injak

Setelah desain selesai dibuat kemudian persiapan alat dan bahan dilakukan di bengkel kerja. Alat berupa mesin las, mesin pemotong atau gerinda, mesin bor, genset, kompresor dan lain-lain. Bahan berupa besi, kran air, tempat sabun, bak cuci, cat, dan lain-lain.

Tahap berikutnya adalah pelaksaan pembuatan wastafel. Pekerjaan ini dimulai dari pemotongan bahan besi sesuai dengan ukuran dalam desain. Pembuatan besi penyangga tandon air, untuk kran air, tempat sabun cair, dan pedal. Setelah pemotongan sesuai ukuran, kemudian dilakukan pengelasan dengan menyambung bagian-bagian yang sesuai untuk membentuk rangka dari wastafel. Memasang masingmasing bagian sesuai desain, tempat keran di pasang dengan menyambungkan dengan besi dengan pedal untuk sistem injak. Dokumentasi pelaksanaan pembuatan wastafel dapat dilihat pada Gambar 4. Bahan-bahan yang sudah dibuat, disambung dan dirakit, kemudian dihaluskan bekas-bekas las dengan kertas gosok dan dempul untuk merapikan bekas las. Wastafel yang sudah dirakit dan dihaluskan, kemudian dibersihkan dari debu agar waktu pengecatan tertutup secara rapi dan halus. Setelah rangka wastafel dibersihkan, kemudian dilakukan pengecatan sesuai dengan warna yang diinginkan. Pengecatan menggunakan penyemprot cat dan kompresor agar merata dan rapi. 


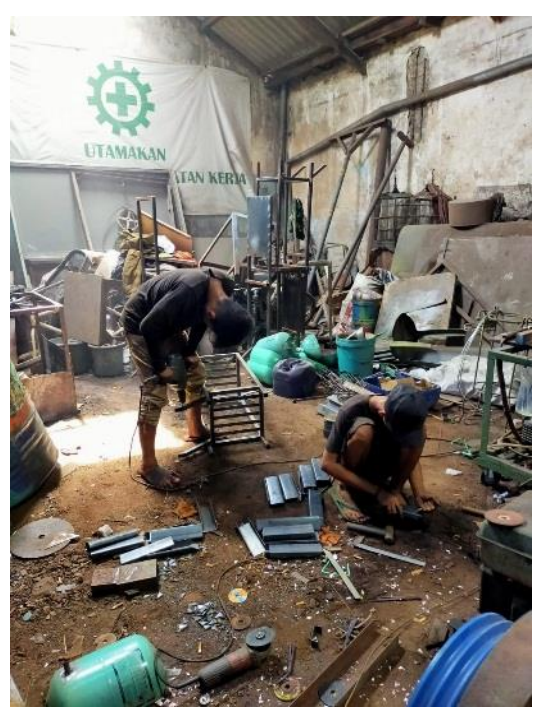

Gambar 4. Pelaksanaan Pembuatan Wastafel

Rangka wastafel yang telah di cat ditunggu sampai kering kemudian dilanjutkan memasang bagianbagian pelengkapnya. Bagian-bagian lain yang dipasang adalah keran air, tempat sabun cair, dan tandon air bersih dan tandon air bekas cuci tangan. Wastafel yang sudah di cat dapat dilihat pada Gambar 5 .

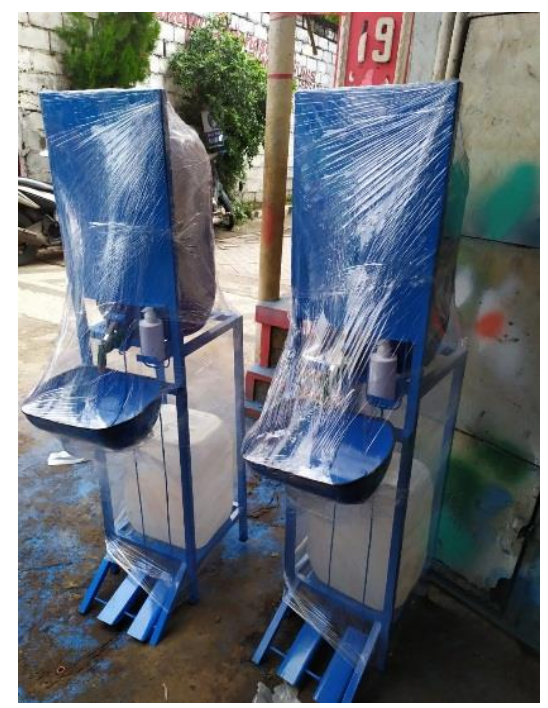

Gambar 5. Wastafel yang telah di cat dan dihaluskan

Terakhir adalah membuat stiker yang berisi poster keterangan tata cara cuci tangan yang benar, kemudian di tempelkan pada tempat papan besi di atas keran air. Logo dan tata cara cuci tangan dapat dilihat pada Gambar 6. Poster Tata cara mencuci tangan yang benar ini sebagai cara untuk meningkatkan pengetahuan mencuci tangan yang benar, karena pengetahuan sangat berpengaruh terhadap perilaku mencuci tangan (Lestari, 2019). 


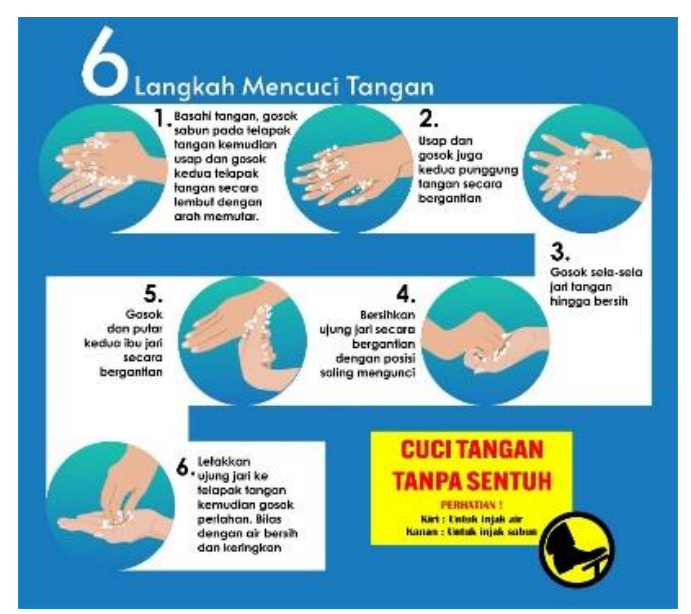

Gambar 6. Stiker Cara Mencuci Tangan dengan Benar

\section{Distribusi Wastafel ke SMK}

Tahap ketiga adalah distribusi ke SMK dan menempatkan wastafel ditampat yang sudah derencanakan berdasarkan hasil survey dan koordinasi dengan SMK. Wastafel yang sudah jadi dan siap digunakan, diangkut dengan mobil pickup diantar dengan urutan pertama ke SMK Negeri 5 Surabaya, kemudian ke SMK Negeri 2 Surabaya, SMK Negeri 7 Surabaya dan terakhir ke SMK Negeri 3 Surabaya. Jumlah wastafel yang didistribusikan berjumlah 8 dengan masing-masing SMK 2 wastafel. Sebelum diantar, Tim sudah menghubungi pihak SMK, sehingga waktu sampai di SMK sudah siap dan disambut baik oleh guru-guru di SMK untuk diarahkan ketempat wastafel diletakkan. Gambar 7 merupakan serah terima wastafel di SMK Negeri 5 Surabaya.

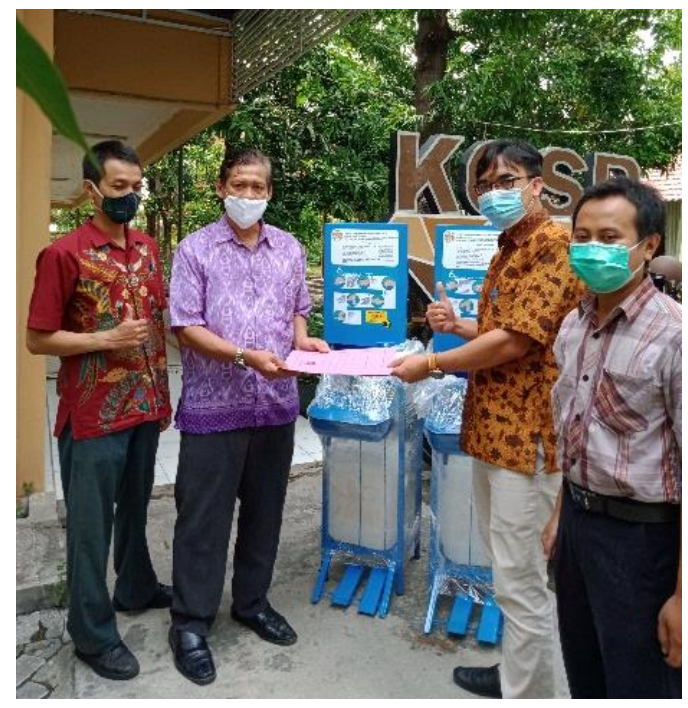

Gambar 7. Penyerahan Wastafel ke SMK Negeri 5 Surabaya

Wastafel portabel dengan sistem injak yang sudah diantar kemudian diletakkan di lokasi seperti di depan ruangan kelas, depan laboratorium atau bengkel kerja dan di depan ruang guru. Ditempat tersebut yang sebelumnya belum ada wastafel portabel dengan sistem injak, sekarang sudah terdapat wastafel tersebut. Respon mitra sebagai evaluasi terhadap PKM pengadaan wastafel portabel sistem 
injak ini sangat baik. Empat SMK memberikan respon positif dan sangat bermanfaat bagi sekolah untuk membantu dalam penerapan protokol kesehatan dimasa adaptasi baru (new normal) ini. Wastafel yang mudah digunakan dan mudah dijangkau akan meningkatkan kebiasaan cuci tangan, karena dengan membiasakan mencuci tangan dapat mencegah penyakit-penyakit pada siswa (Natsir, 2018). Gambar 8 menunjukkan dokumentasi dengan kepala SMK Negeri 3 Surabaya.

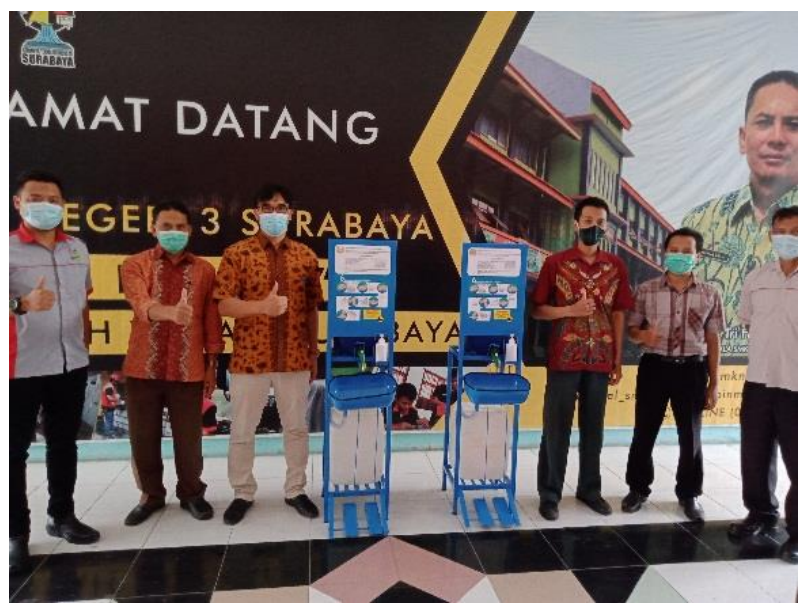

Gambar 8. Penyerahan Wastafel ke SMK Negeri 3 Surabaya

\section{EVALUASI DAN TINDAK LANJUT}

Hasil evaluasi terhadap pelaksanaan Program Pengabdian Kepada Masyarakat "Wastafel Portabel Sistem Injak sebagai Piranti Pendukung Protokol Kesehatan di Masa Adaptasi Baru" ini menunjukkan bahwa wastafel portabel dengan sistem injak sangat baik dan bermanfaat dalam melaksanakan protokol kesehatan yang merupakan salah satu dari 3M yaitu mencuci tangan dengan sabun. Empat SMK menunjukkan hasil yang positif terhadap pengadaan wastafel portabel dengan sistem injak. Pihak SMK merasa sangat terbantu dengan adanya pengadaan wastafel portabel ini. Pihak SMK berharap jumlah wastafel yang diadakan dan didistribusikan ke SMK agar lebih banyak, sehingga memenuhi jumlah kebutuhan di SMK karena rencananya pada tahun 2021 ini sudah mulai pembelajaran tatap muka.

Rencana tindak lanjut hasil Program Pengabdian Kepada Masyarakat "Wastafel Portabel Sistem Injak sebagai Piranti Pendukung Protokol Kesehatan di Masa Adaptasi Baru" ini adalah sebagai berikut:

1. Desain wastafel portabel dengan sistem injak ini apabila berhasil dengan baik digunakan di sekolah, maka bisa digunakan sebagai dasar untuk memproduksi wastafel dengan model yang sama untuk digunakan di tempat yang lainnya dalam rangka mendukung protokol kesehatan.

2. Kerjasama dengan pihak SMK Negeri 2 Surabaya, SMK Negeri 3 Surabaya, SMK Negeri 5 Surabaya, dan SMK Negeri 7 Surabaya akan berkelanjutan baik di pelaksanaan PKM maupun penelitian dan kegiatan lainnya. 


\section{KESIMPULAN}

Kegiatan pengabdian kepada masyarakat dengan mengadakan wastafel portabel sistem injak kepada mitra di empat sekolah yaitu SMK Negeri 2 Surabaya, SMK Negeri 3 Surabaya, SMK Negeri 5 Surabaya, dan SMK Negeri 7 Surabaya telah terlaksana dengan sangat baik dan respon positif diberikan pihak mitra terhadap pelaksanaan PKM. Adapun kegiatan-kegiatan yang telah terlaksana adalah sebagai berikut:

1. Kegiatan koordinasi dan survey ke SMK dengan menghasilkan kerjasama, kesepakatan dan saran desain wastafel.

2. Kegiatan pembuatan wastafel, mulai dari desain wastafel, persiapan alat dan bahan, perakitan, sampai dengan finishing dengan menghasilkan wastafel sistem injak yang siap digunakan.

3. Kegiatan distribusi wastafel ke SMK Negeri 2 Surabaya, SMK Negeri 3 Surabaya, SMK Negeri 5 Surabaya, dan SMK Negeri 7 Surabaya dengan menghasilkan penempatan wastafel di depan ruang kelas, bengkel kerja dan ruang guru yang sebelumnya belum ada wastafel sistem injak, sekarang sudah ada wastafel dengan sistem injak. Respon mitra sebagai evaluasi terhadap PKM pengadaan wastafel portabel sistem injak ini sangat baik dan sangat bermanfaat bagi sekolah.

\section{UCAPAN TERIMAKASIH}

Penulis mengucapkan terima kasih kepada Fakultas Teknik Universitas Negeri Surabaya dan pihak SMK Negeri 2, 3, 5, dan 7 Surabaya yang telah memberi dukungan terhadap kegiatan pengabdian ini.

\section{DAFTAR PUSTAKA}

Ambarwati, E. R., \& Prihastuti, P. (2019). Gerakan Masyarakat Hidup Sehat (Germas) Mencuci Tangan Menggunakan Sabun dan Air Mengalir Sebagai Upaya Untuk Menerapkan Perilaku Hidup Bersih dan Sehat (PHBS) Sejak Dini. Celebes Abdimas: Jurnal Pengabdian Kepada Masyarakat, 1(1), 45-52.

Ibrahim, I., Kamaluddin, K., Mintasrihardi, M., Junaidi, A. M., \& Abd Gani, A. (2020). Bencana Virus Corona melalui Sosialisasi pada Anak Usia Dini pada Desa Rempe Kecamatan Seteluk Sumbawa Barat. Selaparang Jurnal Pengabdian Masyarakat Berkemajuan, 3(2), 191-195.

Kushartanti, R. (2012). Beberapa Faktor yang Mempengaruhi Perilaku Cuci Tangan Pakai Sabun (CTPS)(Studi di Sekolah Dasar Negeri Brebes 3). Universitas Diponegoro.

Lestari. (2019). Hubungan Pengetahuan dan Sikap Terhadap Perilaku Cuci Tangan pada Masyarakat Kelurahan Pegirian. Jurnal Promkes, 7(1), 1-11.

Manikandan, N. (2020). Are Social Distancing, Hand Washing and Wearing Masks Appropriate Measures to Mitigate Transmission of COVID-19? Vacunas (English Edition), 21(2), 136-137. https://doi.org/10.1016/j.vacune.2020.10.010

Nakoe, R., S Lalu, N. A., \& Mohamad, Y. A. (2020). Perbedaan Efektivitas Hand-Sanitizer dengan Cuci Tangan Menggunakan Sabun Sebagai Bentuk Pencegahan Covid-19. Jambura Journal of Health Sciences and Research, 2(2), 65-70. https://doi.org/10.35971/jjhsr.v2i2.6563

Natsir, M. F. (2018). Pengaruh Penyuluhan CTPS Terhadap Peningkatan Pengetahuan Siswa SDN 
169 Bonto Parang Kabupaten Jeneponto. Jurnal Nasional Ilmu Kesehatan (JNIK), 1(2).

Pogrebna, G., \& Kharlamov, A. A. (2020). The Impact of Cross-Cultural Differences in Handwashing Patterns on the COVID-19 Outbreak Magnitude. Research Gate, March, 10. https://doi.org/10.13140/RG.2.2.23764.96649

Przekwas, A., \& Chen, Z. (2020). Washing Hands and The Face may Reduce COVID-19 Infection. Medical Hypotheses, 144(August), 110261. https://doi.org/10.1016/j.mehy.2020.110261

Peraturan Menteri Kesehatan Republik Indonesia No. 3 Tahun 2014 Tentang Sanitasi Total Berbasis Masyarakat, Pub. L. No. 3 (2014).

World Health Organization. (2020). Fight COVID-19 with WHO's Five Heroic Acts. https://www.who.int/campaigns/connecting-the-world-to-combat-coronavirus/safehandschallenge/5-heroic-acts 